\title{
薬物の組織への効率的なデリバリー戦略構築を目指した血管内皮細胞の新たな機能探索と解明
}

\author{
櫻井栄一
}

\section{Elucidation of New Function in Endothelial Cells for Efficient Delivery Strategy of Drug to Tissues}

\author{
Eiichi Sakurai \\ Department of Pharmaceutics, Faculty of Pharmaceutical Sciences, Tokushima Bunri University; \\ 180 Nishihama-Boji, Yamashiro-cho, Tokushima 770-8514, Japan.
}

(Received July 7, 2019)

\begin{abstract}
The author has described two new functions of endothelial cells for efficient delivery of drugs to tissues. First, it was indicated that tight junction (TJ)-associated protein, claudin-1, exerts potent paracellular barrier function in cultured mouse lung microvascular endothelial cells (LMECs). This barrier was instantly and reversibly opened by reduction of TJ proteins expression via histamine $\mathrm{H}_{1}$ and $\mathrm{H}_{2}$ receptors. Histamine was biosynthesized by L-histidine decarboxylase from uptaken L-histidine, and biotransformed by type B of monoamine oxidase, suggesting that histamine concentration is controlled in rat brain MECs (BMECs) and LMECs. Moreover, uptake of L-histidine into BMECs and LMECs markedly increased with addition of $\mathrm{ZnSO}_{4}$. Second, it was suggested that drug-metabolizing enzymes such as $\mathrm{CYP}$ and flavin-containing monooxygenase exist in vascular endothelial cells exposed to blood and to aerobic conditions. These cells have the same ability to metabolize drugs as hepatocytes, demonstrating that vascular endothelial cells are a metabolic barrier against tissue transfer of drugs. From these results, it was suggested that reversible opening of TJ and selective inhibition of drug metabolism in vascular endothelial cells may be efficient delivery strategies of drugs to tissues. Finally, I hope that this research will lead to development of new drugs and possible re-evaluation of discontinued drugs.
\end{abstract}

Key words_— vascular endothelial cells; tight junction protein; histamine; L-histidine; drug-metabolizing enzyme: drug delivery

\section{1.はじめに}

筆者は体内での薬物の動きに魅せられ，東北薬科 大学 (現 東北医科薬科大学) 薬剤学教室 (丹羽弘 司教授）の門を叨いた。この頃，薬剤学は黎明期か ら黄金期へ移る時期でもあった，以来，東北薬科大 学 (講師) に 22 年, 青森大学薬学部 (教授) に 5 年, 徳島文理大学薬学部 (教授) に 10 年間在籍し, 薬剤学教室を主宰した。

当初与えられたテーマは「病態時における薬物の 体内動態の変動について」である.しかし, 薬は本 来病気のときに飲むものだから，と戸惑いつつも薬 理学にも興味があったので，いろいろ考えた末「病 態時の生体成分の変動と薬物動態の機能変化」を中 心に研究を進め, ${ }^{1-3)}$ 現在まで続けてきた. ${ }^{4-6)}$ その

徳島文理大学薬学部薬剂学教室（干770-8514 徳島市山 城町西浜傍示 180)

e-mail: esakuraijp@gmail.com

本総説は, 2018 年度退職にあたり在職中の業績を中心

に記述されたものである.
過程で, 組織毛細血管の機能変化, 特に血管透過性 の克進が薬物の組織移行を高めることを，下痢をモ デルにin vivo 及び組織レベルの検討から見い出 し, タイトジャンクション（tight junction; TJ）の 開口が薬物の組織移行の増加につながる可能性を示 唆した.さらに, そのターゲット物質がヒスタミン であることを突き止めた．当時，薬物の体内動態と ヒスタミンの作用との関係についての研究はそれこ そ異端にみられたと思う。しかし，ヒスタミン研究 の第一人者として世界をリードしていた渡邊建彦先 生が大阪大学医学部から東北大学医学部第一薬理学 教室に教授として就任されたことから，同じ仙台の 地で共同研究をする機会に恵まれ，薬物動態との関 係を遺伝子レベルまで飛躍的に研究を発展させるこ とができた.

他方, 私の大学院時代には, 「薬物の代謝酵素活 性を測定する」という目的について，考えられる代 謝物の合成を片つ端から行ってきた。 そのことが, 薬物動態学の研究の 1 つの流れとしてモレキュ 
ラー・キラリティーへと進み, 結果として病態時に キラル識別が容易に失われる可能性を見い出し

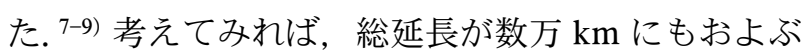
と言われる血管に存在する内皮細胞は，常に血液と 接し好気的条件下に曝されていることを思えば，こ こに薬物代謝酵素が存在することで容易に薬物が代 謝され，組織への薬物移行を妨げている可能性が十 分予想される.

周知の通り, 薬物の組織移行量は, 効果に直結す る. したがって in vitroで優れた効果を示す薬物が 合成されても組織移行性が悪ければ，この段階でド ロップアウトしてしまう。血液中に運ばれた薬物が 組織に移行する際，第一関門となるのが先に述べた 組織毛細血管の内皮細胞であり，血液組織関門を構 成する.これまで, 薬物の組織移行については主に 血液組織関門におけるトランスポーターに関する研 究に焦点が当てられていた。 しかし，薬物の効率的 な組織へのデリバリー戦略を考えるには，血管内皮 細胞の新たな機能の探索と解明が必要となる。本総 説において，その概要を説明したい.

\section{TJ の形成とその開口}

微小血管内皮細胞における物質輸送経路には, 細 胞間隙経路とトランスポーターやレセプターを介し た経細胞経路がある. 微小血管内皮細胞の細胞間接 着装置である $\mathrm{TJ}$ は，細胞間隙経路での物質透過を 制御してバリアー機能を有している．TJ の構造と 機能を担う分子基盤は, Claudin, Occludin 及び ZO である. Claudin と Occludin は 4 回膜貫通型夕 ンパク質で，2つの細胞外ループを持ち，その $\mathrm{N}$ 末と $\mathrm{C}$ 末は細胞質に存在し， C 末で $\mathrm{TJ}$ の特異的な 裏打ちタンパク質 ZO と結合している. このうち,

Claudin は 1998 年に古瀬らによって発見された. ${ }^{10)}$ Claudin-1 又は Claudin-2 をタイト結合しない線維 芽細胞で発現させると，タイト結合ストランドを形 成することから Claudin がタイト結合の基本骨格を 形成していることがわかつた. ${ }^{11)}$ 現在 Claudin ファ ミリーは 27 種類のメンバーが存在し，この発現及 びバリアー機能には組織特異性が認められ, 12) その 組織特異性に基づいた Claudin をターゲットとした 新規薬物吸収促進剂の開発が近年注目されてい る. ${ }^{13)}$ Claudin は炎症を生じる病態やクロストリジ ウム属の産生するエンテロトキシンにより，その発 現量が変動するとの報告もあり, ${ }^{14)} \mathrm{TJ}$ 開口に Clau-

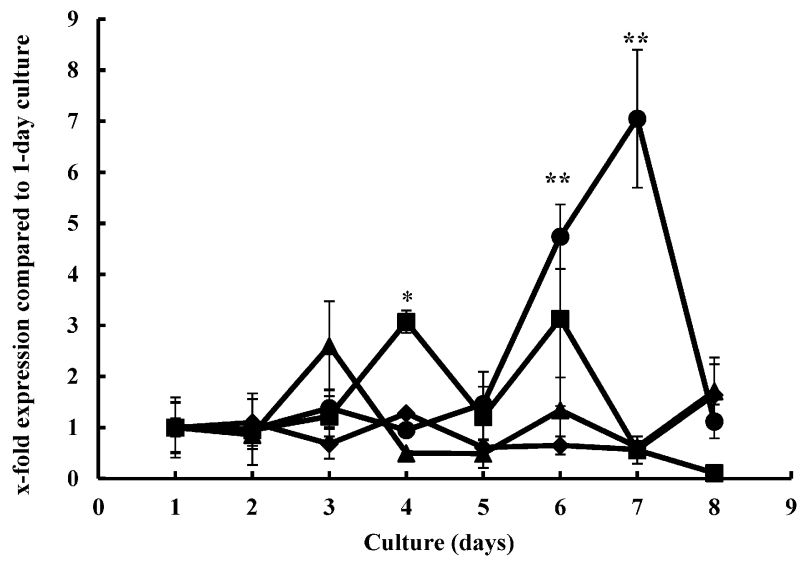

Fig. 1. Quantification of Occludin ( $\mathbf{\Delta})$, Claudin-1 (O) and $-4(\boldsymbol{\square})$ and ZO-1 $(\bullet)$ mRNAs by Real-time PCR in Cultured Mouse LMECs

The level of each mRNA on day 1 in culture was used as a basal level to compare relative levels at the other culture times. ${ }^{*} p<0.05$ and ${ }^{* *} p<0.01$ for comparison with each basal level. Each value is expressed as the mean \pm S.E. of five experiments.

din が関与していることが想定できる.

2-1. 肺微小血管内皮細胞における Occludin，

Claudin，ZO-1 の遺伝子及びタンパク質の発現 まず本研究で, 培養マウス肺微小血管内皮細胞 (lung microvascular endothelial cells; LMECs)の Occludin, Claudin 及び ZO の遺伝子発現及びタン パク質の発現を検討した。二世代培養マウス LMECs を播種後, TJ タンパク質の mRNA をリア ルタイムRT-PCR で測定した。その結果，1 日目 から Occludin, Claudin-1, Claudin-4 及び ZO-1の mRNA 発現が確認された。播種 1 日目の mRNA 発 現レベルを基準とすると, Occludin, Claudin-4 及 び ZO-1 は 8 日目まで有意な増加が認められなかっ た。これに対し，Claudin-1 mRNA レベルは 6 日目 から有意に増加し，7 日目には基準值（1日目）の 約 7 倍に達し，その後 8 日目には基準レベルまでに 下がった（Fig. 1). 15) さらに，培養マウス LMECs をフラスコに播種し，コンフルエントに達した培養 6 日目の TJ タンパク質をウエスタンブロット法で 検討したところ，Occludin，Claudin-1，Claudin-4 及びZO-1 のタンパク質の発現がそれぞれ認められ た.

2-2. 経内皮電気抵抗及び細胞間隙透過クリアラ ンス 肺の毛細血管から単離培養された内皮細胞 は，がん化された継代細胞と異なり，毛細血管内皮 細胞をフラスコあるいはトランスウエルに培養した 場合，微小血管内皮細胞は初代及び培養二世代ま 
で，血液に接している側が培養液側に向き，組織側 が培養器に接着し単層培養される性質を持つ。 その ため, 目的物質に対して方向性のあるべクトル輸送 の測定ができる。そこで，培養マウス LMECs をト ランスウエルに播種し, 電極を用い経内皮電気抵抗 (transendothelial electrical resistance; TEER) の測 定及び細胞間隙経路の夕通過するフルオレセインを 用いて，細胞間隙透過クリアランスの測定を行っ た。培養マウス LMECs は, 培養 6-8 日後にコンフ ルエントに達した。培養マウス LMECs の TEER 值は 2 日目より経日的に上昇し，培養 6-7 日目に $19.0 \pm 2.9 \Omega \times \mathrm{cm}^{2}$ となり最大值に達した［Fig. 2 (a) ]. ${ }^{15)}$ この值は他の報告のコンフルエントに達し た培養ラット肺微小血管内皮細胞16)の值と類似して いたが，ラット脳微小血管内皮細胞より約 $20 \%$ 低 かった. ${ }^{17,18)}$ 培養マウス LMECs の細胞間隙透過ク リアランス值は経日的に減少し培養 5-8 日目に最も 低い值を示した $[$ Fig. 2(b) ]. 15) このことから，培 養 6-7 日目に細胞間密着が強固になり，透過バリ アーが形成されると考えられる。Colegio らは, Claudin 発現の変化が経上皮電気抵抗及び透過性に 影響があることを明らかにしている. ${ }^{19,20)}$ また， Nitta らは脳の毛細血管内皮細胞に選択的に発現し ている Claudin-5 のノックアウトマウスで血液脳関 門（blood-brain barrier; BBB）の透過性が充進し, 透過した分子量は $800 \mathrm{Da}$ 以下で分子量に対して選 択的であると報告している. ${ }^{21)}$ 本実験から得られた 遺伝子発現デー夕と考え合わせると, 組織により Claudin のタンパク質発現に分子種の違いはある が，培養マウス LMECs における TJ の形成には Claudin-1 が大きく関与することが考えられた. ${ }^{15)}$ 培養マウス LMECs の TJ が確立されたことから, $\mathrm{TJ}$ の開口について，その評価検討が可能になつた.

\section{2-3. 微小血管内皮細胞の $\mathbf{T J}$ 開口物質の探索}

1.で述べたように，in vivo 及び組織レベルで得 られた結果を基に，ヒスタミンを開口物質の 1 つと して細胞及び遺伝子レベルでの研究を進めた.

ヒスタミンは，その大部分が好塩基球や肥満細胞 に存在しているが，免疫系及び物理的な刺激により 血中に遊離され，これが持続的に内皮細胞を刺激す ると浮腫を引起こすことが知られている。しかし，

一過性にヒスタミンが細胞間隙を刺激することによ り，可逆的に TJ が開口すれば薬物が組織へ移行し (a)

(b)
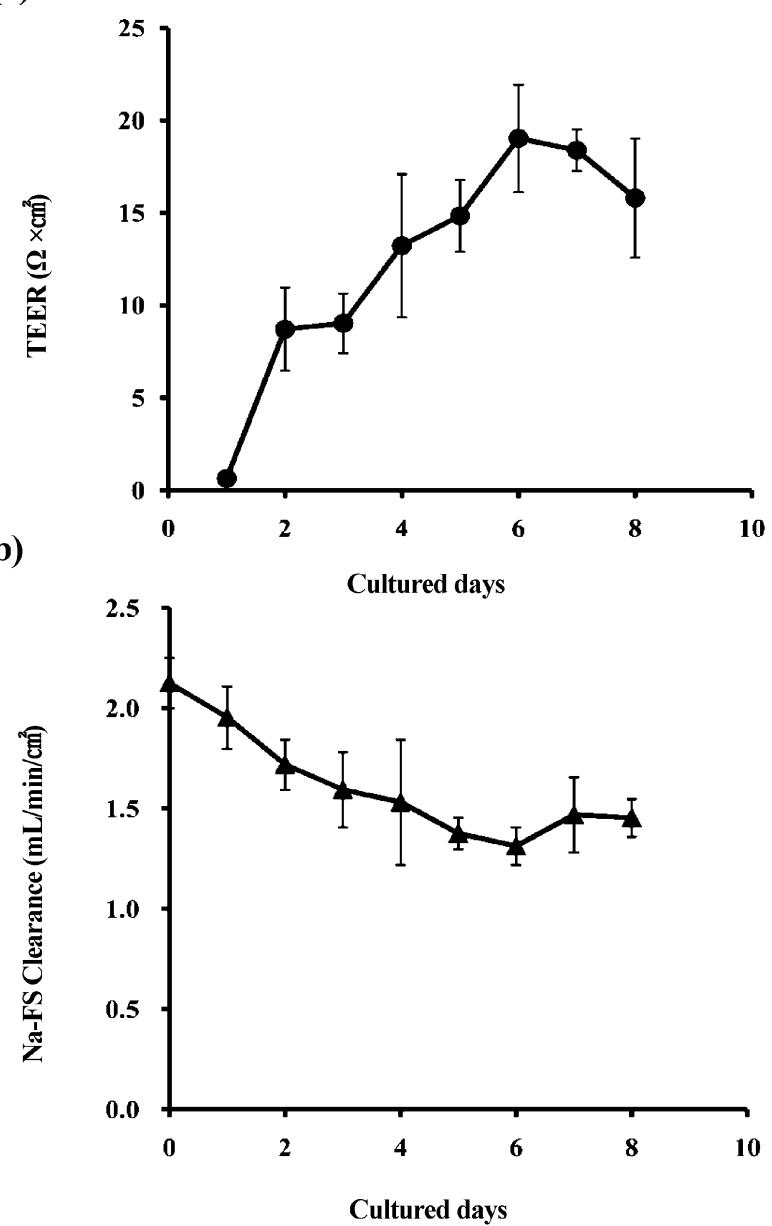

Fig. 2. (a) The Induction of Transendothelial Electrical Resistance (TEER) in Mouse LMECs, and (b) Transendothelial Permeability (Na-FS clearance) Changes for Paracellular Permeability Marker Na-FS in Mouse LMECs Monolayer

(a) Values of TEER are expressed as the mean \pm S.E. of five experiments. (b) Each value is expressed as the mean \pm S.E. of five experiments.

易くなり，薬物の効率的なデリバリーが可能になる と考えられる，そこで筆者は，血中in vivo マイク ロダイアリシス法により，ヒスタミンの腹腔内投与 後の血中ヒスタミン濃度変化をリアルタイムで測定 した．ヒスタミンは 30 分後にはピークに達しその 後一過性に消失することがわかった。ささに，ヒス タミン遊離物質である compound 48/80 を同様に腹 腔内投与すると一過性の遊離パターンが認められ た. ${ }^{22)}$ ヒスタミンは，一見悪玉物質に捉えられがち であるが，ヒスタミンの血中消失パターンをうまく 利用できれば，TJ開口に対する素晴らしい物質の 1 つになり得ることは容易に推定できる.

そこで，トランスウエルに播種し，透過バリアー の形成を確認した培養マウス LMECsに $10 \mu \mathrm{mol} / \mathrm{L}$ 
のヒスタミンを添加すると， 5 分で透過性が六進 し, 約 1 時間までフルオレセインの細胞間隙透過ク リアランスがコントロール群と比べて有意に上昇し た.しかし，ヒスタミン添加 3 時間後にはフルオレ セインの細胞間隙透過クリアランスが回復し，ヒス タミンによる TJ の開口が可逆的であることが明ら かになった（Fig. 3). また, 現在投稿中であるが, ヒスタミンの添加によって Occludin, Claudin-4 及 び ZO-1 の mRNA レベルが添加後のかなり早い段 階で減少していることがわかつた。この現象に対し て, ヒスタミン $\mathrm{H}_{1}$ 受容体拮抗薬であるメピラミン 及び $\mathrm{H}_{2}$ 受容体拮抗薬であるシメチジンの添加に よって透過クリアランスは減少しオリジナルレベル に回復した。このことから，ヒスタミンは膜受容体 である $\mathrm{H}_{1}$ あるいは $\mathrm{H}_{2}$ 受容体に結合し，プロテイ ンキナーゼ A 及びプロテインキナーゼ C を活性化 させ TJ タンパク発現を抑制し，TJ 開口させる ことが推測された。

2-4. 微小血管内皮細胞におけるヒスタミンの産 生ヒヒスタミンは L-ヒスチジン脱炭酸酵素（Lhistidine decarboxylase; HDC）により L-ヒスチジ ンから生成される。 そこで, ラット脳微小血管内皮 細胞 (brain microvascular endothelial cells; BMECs) がヒスタミン産生能を持つか確認するため, 細胞内 HDC の存在について検討した. ${ }^{23)}$

BMECs におけるヒスタミン産生酵素である HDC の活性值は $0.14 \pm 0.05 \mathrm{pmol} / \mathrm{mg}$ protein $/ \mathrm{min}$ であり (Table 1). 23)この活性は HDC の特異的阻 害剂である $\alpha$-フルオロメチルヒスチジンにより阻 害された（Fig. 4). ${ }^{23)}$ また，ラット好塩基球性白血 病細胞に比較するとその発現は少ないものの, BMECs に HDC の mRNA の存在が確認された. さらに, HDC 抗体を用い免疫蛍光染色を行ったと ころ，BMECs に HDC の酵素タンパク質の存在を 確認した.

2-5. 微小血管内皮細胞におけるヒスタミンの代 謝ヒスタミンは，N-メチルトランスフェラー ゼにより $N$-tele-メチルヒスタミンに，そしてモノ アミン酸化酵素 (monoamine oxygenase; MAO) のBタイプ（type B of MAO; MAO-B）によりさら に代謝を受ける。筆者は，MAO の研究に従事する チャンスを頂き, スウェーデンウプサラ大学バイオ メディカルセンターに留学した。この頃はまだ,

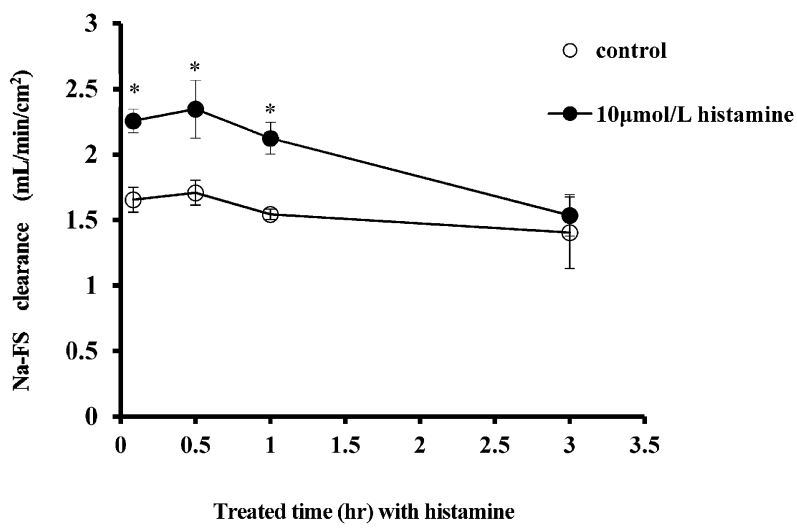

Fig. 3. Effect of Histamine on Transendothelial Permeability of Na-FS in Mouse LMECs Monolayer

Each value is expressed as the mean \pm S.E. of four experiments. ${ }^{*} p<$ 0.05 , compared with control.

Table 1. Regulation of Histamine Biosynthesis in Rat BMECs

$\begin{array}{ll}\text { Histidine }(\mathrm{nmol} / \mathrm{mg} \text { protein }) & 3.00 \pm 0.14 \\ \text { HDC }(\mathrm{pmol} / \mathrm{mg} \text { protein } / \mathrm{min}) & 0.14 \pm 0.05 \\ \text { Histamine }(\mathrm{pmol} / \mathrm{mg} \text { protein }) & 2.18 \pm 0.10\end{array}$

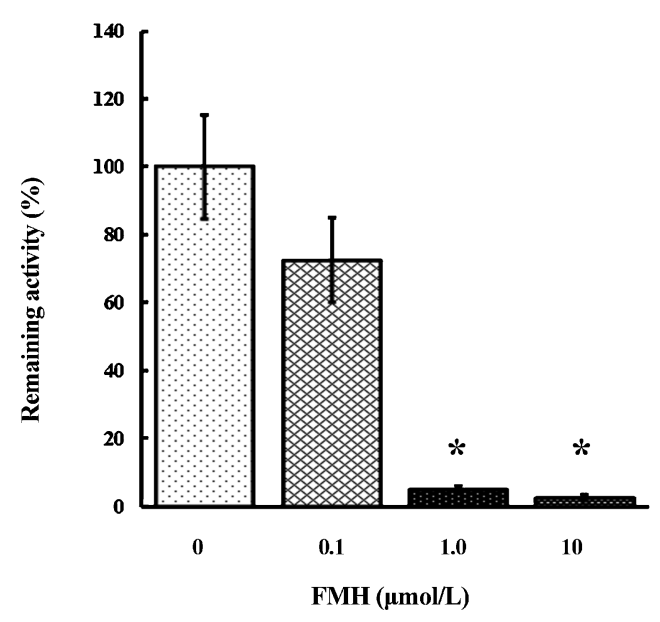

Fig. 4. Inactivation of HDC Activity by (S) - $\alpha$-fluoromethylhistidine (FMH) in Rat BMECs

Samples containing HDC activity were preincubated with various concentrations of FMH for $30 \mathrm{~min}$, then the remaining HDC activity was assayed. ${ }^{*} p<0.01$, compared with control.

MAO と微小血管内皮細胞内のヒスタミン代謝機能 についての発想には至っていなかった。 ウプサラ大 学医学部の Lars Oreland 教授の下, 当時, 「拒食症 や過食症における血小板 MAO 活性とセロトニン 取り込み・遊離との関係」24)などの論文をまとめ た．脳のサンプルを直接取ることなしに，血小板の $\mathrm{MAO}$ 活性とモノアミン動態から脳疾患のメカニズ ムを解明するという画期的な研究結果を報告するこ 
(a)

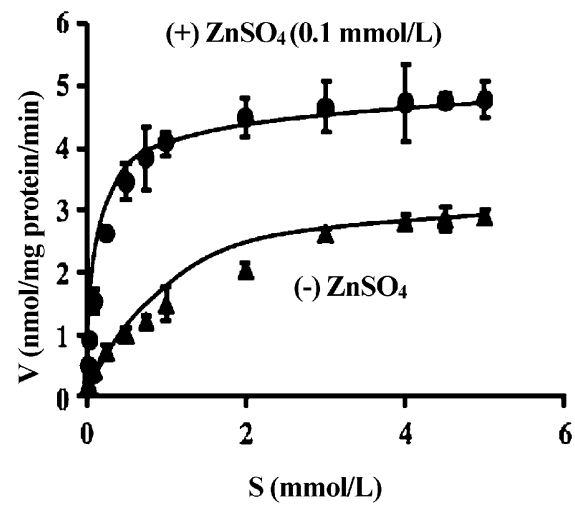

(b)

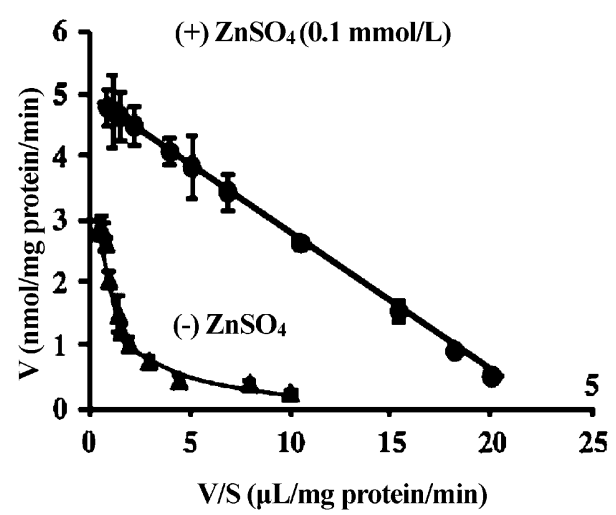

Fig. 5. Concentration Dependence of L-Histidine Uptake by Cultured Monolayers of Rat LMECs in the Absence ( $\boldsymbol{\Delta}$ ) or Presence (O) of $\mathrm{ZnSO}_{4}$

(a) Michaelis-Menten and (b) Eadie-Hofstee plots. L-Histidine uptake at concentrations between 0.01 and $3 \mathrm{mmol} / \mathrm{L}$ was determined at $37^{\circ} \mathrm{C}$ for 2 min. Each point represents the mean \pm S.E. of four determinations. V, L-Histidine uptake rate (nmol/mg protein $/ \mathrm{min}) ; \mathrm{S}$, L-histidine concentration $(\mathrm{mmol} / \mathrm{L})$.

とができた。このような経緯を経て，BBBと MAO の関係についての着想に至り，現在まだ予試 験の段階ではあるが免疫蛍光染色法により，BBB を構成するラット BMECs に MAO-B の存在とその 酵素活性のあることが明らかになってきている。

2-6. ヒスタミン前駆体である L-ヒスチジンの微 小血管内皮細胞内取り込み メカニズムの詳細は 後述するが，筆者は，ラット脳 ${ }^{25)}$ 及び肺 ${ }^{26)}$ 微小血管 内皮細胞における $\mathrm{L}$-ヒスチジンは $\mathrm{Na}^{+}$依存性共輸 送型トランスポーターSystem-N 輸送系及び促進拡 散型トランスポーターSystem-L 輸送系で取り込ま れること, 組織の違いによる取り込夕機構に大きな 差は認められないことを明らかにした.

したがって，ヒスタミンは微小血管内皮細胞にお いてその生成が制御されていると考えられる。 そこ で，L-ヒスチジンの取り込みの増大，HDC 活性の 誘導あるいはヒスタミン代謝の抑制によって細胞内 のヒスタミン産生を増加させることができれば，効 率よい TJ 開口につながるのではと考た。まず, L-ヒスチジンの取り込みを増加させる物質の探索を 行つた.

2-7. L-ヒスチジンの微小血管内皮細胞内取り込 みを増加させる物質の探索Ｌ-ヒスチジンは機能 タンパクの成分としてイミダゾール基を持ち，イミ ダゾール基が酵素の活性中心で触媒作用に関与し, 金属（亜鉛，銅，鉄など）との結合部位になるなど 様々な役割を演じていることが報告されてい
る. ${ }^{27,28)}$ 特に, 亜鉛との生理的相互作用についての 報告は数多く見受けられる. ${ }^{29,30)}$ 亜鉛は, 生体の至 る部位に分布し $60 \mathrm{~kg}$ 体重の人で体内総量は約 $2 \mathrm{~g}$ であり鉄の次に多い. 鉄は血液中にへモグロビンと して存在することから考えると，亜鉛は細胞内では 最も多い必須微量金属であると言える，血液中にお いて亜鉛は主として高分子リガンドであるアルブミ ン, トランスフェリンと結合し，イオン型はわずか である、しかし，その一部はアミノ酸などの低分子 リガンドと結合しており, 中でも L-ヒスチジンが 最も亜鉛に対して親和性の高いリガンドとして知ら

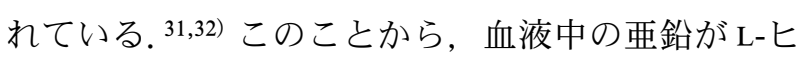
スチジンの細胞内輸送に対してなんらかの影響をお よぼしている可能性が考えられた。 そこで，亜鉛添 加による L-ヒスチジンの取り込み増加作用につい て検討した.

亜鉛の添加により L-ヒスチジンの取り込み速度 は無添加時に比べ約 4 倍と顕著に増加した。 L-ヒス チジンの培養ラット LMECsへの取り込み速度は反 応時間に依存し, 添加後 2.5 分まで直線性が認めら れた。 そのため取り込みに関する実験はすべて 2 分 で行った。なお，亜鉛は血液中濃度に比べ 10 倍量 にあたる $0.1 \mathrm{mmol} / \mathrm{L}$ を添加した. Figure $5(\mathrm{a})^{33)}$ に 示したように, Michaelis-Menten プロットの解析か ら L-ヒスチジンの取り込み速度に飽和が認めら れ, トランスポーターを介した輸送系が示唆された.

Figure 5 (b) ${ }^{33)}$ の Eadie-Hofstee プロットの解析か 
(a) $\quad(-) \mathrm{ZnSO}_{4}$

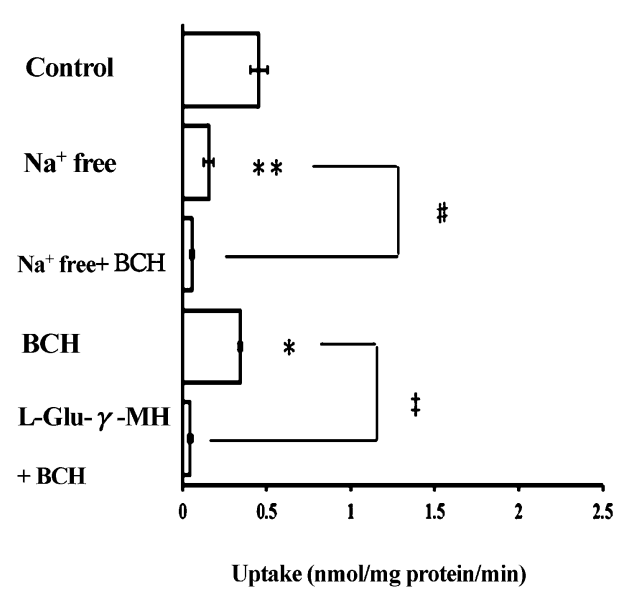

(b) $\quad(+) \mathrm{ZnSO}_{4}(0.1 \mathrm{mmol} / \mathrm{L})$

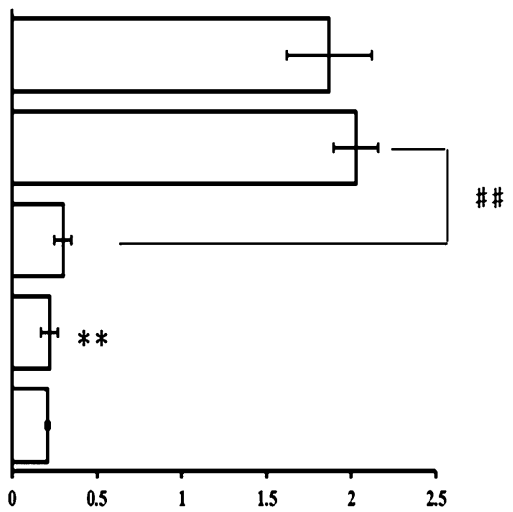

Uptake (nmol/mg protein/min)

Fig. 6. Uptake Rates of L-Histidine into Rat LMECs in the Absence (a) or Presence (b) of $\mathrm{ZnSO}_{4}$

Measurements were made in $143 \mathrm{mmol} / \mathrm{L} \mathrm{Na}^{+}$(control), $\mathrm{Na}^{+}$-free, $\mathrm{Na}^{+}$-free $+1 \mathrm{mmol} / \mathrm{L} \mathrm{BCH}$ and $143 \mathrm{mmol} / \mathrm{L} \mathrm{Na}^{+}+1 \mathrm{mmol} / \mathrm{L} \mathrm{BCH}$, and then in $1 \mathrm{mmol}$ $/ \mathrm{L} \mathrm{BCH}+1 \mathrm{mmol} / \mathrm{L} \mathrm{L}-\mathrm{Glu}-\gamma-\mathrm{MH}$, to inhibit uptake via the $\mathrm{Na}^{+}$-dependent system-N in the presence of $143 \mathrm{mmol} / \mathrm{L} \mathrm{Na}^{+}$. Each point represents the mean \pm S.E. of four determinations. ${ }^{*} p<0.05$ and ${ }^{* *} p<0.01$ significant differences from the control. ${ }^{*} p<0.05$ and ${ }^{*} p<0.01$ significant differences between $\mathrm{Na}^{+}$-free and $\mathrm{Na}^{+}$ -free $+1 \mathrm{mmol} / \mathrm{L} \mathrm{BCH} .{ }^{\ddagger} p<0.01$ significant differences between $1 \mathrm{mmol} / \mathrm{L} \mathrm{BCH}$ and $1 \mathrm{mmol} / \mathrm{L}$ L-Glu- $\gamma$-MH $+1 \mathrm{mmol} / \mathrm{L}$ BCH. BCH: 2-amino-2-norbornanecarboxylic acid (system-L transporter), L-Glu- $\gamma$-MH: L-glutamic acid $\gamma$-monohydroxamate (system-N transporter).

ら，亜鉛を添加するとL-ヒスチジン単独の場合に 認められた二相性の取り込みは示さず，一相性とな り亜鉛添加による輸送は 1 つの System 系だけが関 与することが考えられた。

他方，HDC 活性におよぼす亜鉛の影響を検討し たが，亜鉛が存在してもHDC 活性には影響がない ことが明らかになった。

さらに, ATP 合成阻害剤である 2,4-ジニトロ フェノール (2,4-dinitrophenol; DNP) の前処理, 及び Krebs buffer 中の塩化ナトリウムを塩化コリン に置換した $\mathrm{Na}^{+}$free 溶液を使用して L-ヒスチジン 取り込みを検討した。L-ヒスチジン単独では, DNP 前処理でも, $\mathrm{Na}^{+}$free 溶液でも L-ヒスチジン の取り込み量は有意に低下した。しかし，これに亜 鉛を添加した場合には DNP 前処理でも, $\mathrm{Na}^{+}$free 溶液でも，L-ヒスチジンの取り込みは抑制されな かった。次に，亜鉛添加による L-ヒスチジン取り 込みにおよぼすアミノ酸輸送系阻害剤の影響を検討 した。促進拡散輸送系の阻害剂である 2-amino-2norbornanecarboxylic acid（BCH）を用いた検討で は, $\mathrm{Na}^{+}$free 溶液と比較して, $\mathrm{Na}^{+}$free 溶液に $\mathrm{BCH}$ を添加すると, L-ヒスチジンの取り込みが単 独及び覀鉛添加でともに有意に阻害された（Fig. 6). ${ }^{33)}$ 能動輸送系の阻害剤である L-glutamic acid $\gamma$ monohydroxamate（L-Glu- $\gamma$-MH） を用いて検討し
たところ， BCH と L-Glu- $\gamma$-MH を添加すると単独 では有意な阻害がみられたが，亜鉛添加時の条件で は阻害は認められなかった（Fig. 6)。なお，この 実験系では促進拡散系の影響を除くため $\mathrm{BCH}$ を添 加した群を対照とした。これらのことから，亜鉛を 添加することにより L-ヒスチジン単独で観察され た $\mathrm{Na}^{+}$依存性共輸送型 System-N 系による L-ヒス チジン取り込みは消失し，促進拡散型トランスポー ターSystem-L のみで細胞内へ輸送されることが判 明した。一方， L-ヒスチジンの亜鉛添加と非添加で の $\mathrm{pH}$ による取り込みの影響を検討したところ，

L-ヒスチジン単独と L-ヒスタミンと亜鉛の添加群と の取り込みでは $\mathrm{pH}$ による有意な差はなく, 水素个 オンによる影響は認められないという結果になつ た. ${ }^{33)}$

これまでの結果から，ヒスタミンは LMECs の膜 表面にある $\mathrm{H}_{1}$ 及び $\mathrm{H}_{2}$ 受容体を介した $\mathrm{TJ}$ タンパク 質発現の低下によって，フルオレセインの細胞間隙 透過クリアランスを一時的に上昇させ，薬物の組織 移行を瞬時に増加させる可能性が示唆された。ま た，亜鉛は LMECsへの L-ヒスチジンの取り込みを 増加させ, 結果として LMECs 内でヒスタミン産生 が促進されることが推測された，現在，細胞内で産 生されたヒスタミンの核内受容体の結合と $\mathrm{TJ}$ 開口 との関係について研究を進め, 培養液に直接添加さ 
れたヒスタミンの作用と比較することを試みている.

\section{3. 脳と肺の微小血管内皮細胞及び胸部大動脈血} 管内皮細胞における薬物代謝能力

わが国では，うつ病で入院，通院中の患者，そし て他の気分障害を含めると神経精神疾患患者は数十 万人と言われていて，潜在的患者はさらに多くこの 10 倍以上と推定されている. また, 自殺, パニッ ク障害, 感情障害を持つニートは現代日本，いや世 界の社会問題となっている. したがって，早急な薬 物療法の確立は必然的に求められている. 現在抗う つ薬は第四世代まで開発が進んでいるが，抗うつ薬 は古くから指摘されているように遅効性である，筆 者は薬物動態学的観点から, 脳内への抗うつ薬の送 達で大きな障害になるのは BBB の通過過程ではな いかと考えた。中枢で薬効を速やかに発揮させるに は，いかにしてこのバリアーを突破させ，脳内へ薬 物を送達させるかが鍵になる。 BBB を構成する脳 毛細血管内皮細胞は常に好気的条件下に曝されてい るため, ここに薬物代謝酵素が備わっていれば解毒 （薬物代謝）作用がバリアーの 1 つの機能をして働 いている可能性がある. すなわち，ここでの薬物代 謝の選択的回避が，中枢への薬物デリバリー戦略に かかせないものであると筆者は考えた．胸部大動脈 血管は経肺吸収された薬物が最初に通過する血管で あり，薬物が標的組織に到達する前に，動脈血管の 内皮細胞で代謝を受けると, 組織移行性は低くな る. したがって, 総延長が数万 $\mathrm{km}$ にもおよぶと言 われている動脈血管の内皮細胞や組織に接触してい る毛細血管の内皮細胞での代謝能力は肝や小腸での 代謝能力に匹敵しているかもしれないと推定してい る.

3-1. 脳微小血管内皮細胞内のフラビン含有モノ オキシゲナーゼタンパク質の発現とその活性 フ ラビン含有モノオキシゲナーゼ (flavin-containing monooxygenase; FMO) は, 求核性へテロ原子含有 薬物及び生体異物と反応して，N-及び $S$-酸化する 哺乳動物の非 CYP 酸化酵素である. ${ }^{34)} 5$ つの FMO 分子種がヒト及びマウスにおいて同定されており, 化学反応を触媒する場合 NADPH 及び酸素を必要 とする，FMO 発現は，種，組織，年齢及び性別に 依存する。興味深いことに, FMO1 は胎児のヒト 肝臓で見い出されるが, 出生後の酵素発現の著しい 変化の過程で, 年月の経過とともにヒト FMO では
FMO3 が優勢になる. ${ }^{35,36)}$ マウスでは雌雄ともに, FMO1 タンパク質は高発現されるが, 肝 FMO3 タ ンパク質は雌に対して性特異的に発現している. ${ }^{37)}$ ラット及びマウスの性ホルモンは FMO1 及び FMO3 の発現を調節し, ${ }^{38-41)}$ グルココルチコイド及 び $17 \beta$-エストラジオールは，げっ歯類及びヒトに おいて FMO1 及び FMO3 遺伝子転写の調節因子で あると考えられている. ${ }^{42,43)} \mathrm{FMO} 3$ は，主要ヒ卜肝 蔵 CYP3A4 と同様の発現量で存在する。 ${ }^{44)} \mathrm{FMO} 4$ タンパク質は，ヒト及びマウスの肝臓で発現され る45)が，FMO4 はヒトの薬物代謝に大きく関与し ない. ${ }^{46)} \mathrm{FMO} 2$ は，ヒトの肝臓でほとんど発現され ない. ${ }^{47)}$ FMO5 は，マウス ${ }^{48)}$ 及びヒト ${ }^{49)}$ の肝臓で高 発現される。しか，マウス FMO5によって代謝 されることが知られている化学物質はほんのわずか であり, ${ }^{50)}$ FMO5 の異物代謝への関与は明らかでは ない。したがって，FMOに関して述べると，

FMO1 及び FMO3 が，化学物質の代謝に関して FMO 分子種の中で最も重要であると考えられてい る. ${ }^{51)}$ ヒト脳ミクロソームに関して, 抗精神病薬で あるクロルプロマジン， イミプラミン，フルオキセ チンは FMO で代謝されるという報告があるが, ${ }^{52)}$ FMO 分子種, 活性の強さや酵素バリアーとしての 役割については不明な点が多い。筆者は，単離培養 したラット BMECs の FMO 活性に係わる分子種を 調べるために $d$-クロルフェニラミンの FMO 代謝で 調べた。

培養ラット BMECs ホモジネートに, NADPH 再 生系存在下で, $d$-クロルフェニラミン代謝に対する $\mathrm{pH}$ の影響を検討し, 生成物 $d$-クロルフェニラミン $N$-酸化体の生成を測定した。その值を MichaelisMenten 式にあてはめると, pH 7.4 条件下に比べて $\mathrm{pH} 8.4$ の条件下で, 高い $K_{\mathrm{m}}$ 值と $V_{\max }$ 值が得られ た. $N$-酸化への代謝クリアランス值 $\left(V_{\max } / K_{\mathrm{m}}\right)$ は pH 7.4 条件下よりも, pH 8.4 条件下で約 1.3 倍高 い值であった. FMO は至適 $\mathrm{pH}$ が $\mathrm{pH} 8.5$ 付近にあ る53)ことから， $d$-クロルフェニラミン $N$-酸化体の 生成に FMO が関与する可能性がある。また，培養 ラット BMECs ホモジネートに FMO の代表的な基 質メチマゾール ${ }^{54)}$ を添加し， $d$-フェニルクロラミン の $N$-酸化活性を検討したところ，メチマゾールは $d$-クロルフェニラミン $N$-酸化体生成を，用量依存 的に阻害，このときの $\mathrm{IC}_{50}$ は $1 \mu \mathrm{mol} / \mathrm{L}$ と算出され 


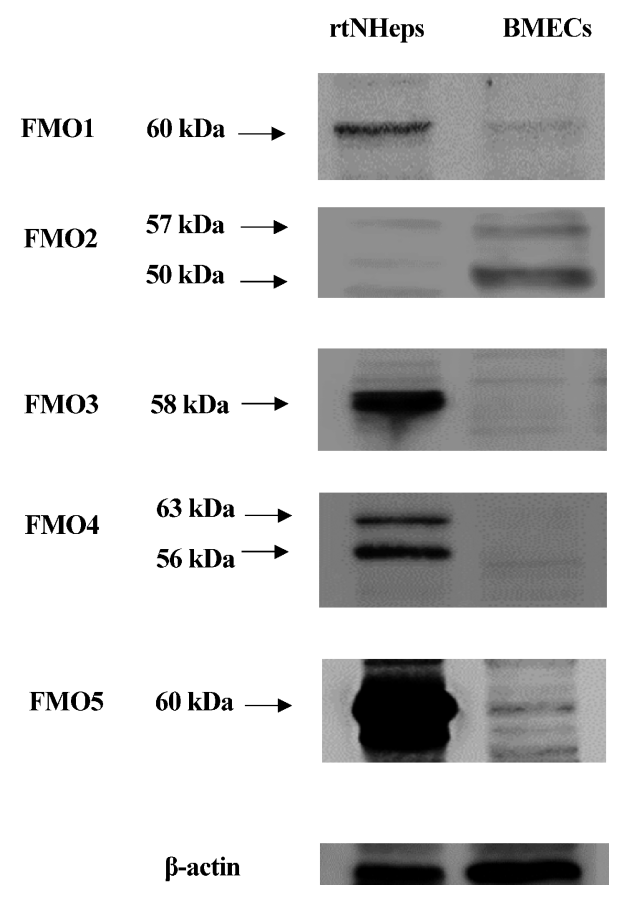

Fig. 7. Western Blots for FMOs in Rat BMECs

た. そこで，メチマゾール $1 \mu \mathrm{mol} / \mathrm{L}$ を添加したと きの $d$-クロルフェニラミン $N$-酸化体生成量を測定 した結果を Lineweaver-Burk プロットで解析したと ころ，その阻害様式は競合的であることが明らかに なり，阻害定数 $K_{\mathrm{i}}$ 值は $0.53 \mu \mathrm{mol} / \mathrm{L}$ が得られた.

また，培養ラット BMECs に発現する FMO 分子 種をウエスタンブロット分析を用いて検索すると, FMO1，FMO2 及び FMO5 の発現が認められた。 しかし, FMO3 と FMO4 は検出限界以下であった (Fig. 7). ${ }^{55)}$ ここで, Eadie-Hofstee プロット解析し たところ，N-酸化体生成は $\mathrm{pH} 7.4$ 及び $\mathrm{pH} 8.4$ 条 件下で一相性を示した。これらの結果は培養ラット
Table 2. Formation of $d$-Chlorpheniramine $N$-Oxide from $d$ Chlorpheniramine in Rat BMECs and rtNHeps

\begin{tabular}{lcc}
\hline \hline & BMECs & rtNHeps \\
\hline $\begin{array}{l}\text { N-Oxidation formation rate } \\
\text { (nmol/mg protein/min) }\end{array}$ & $6.73 \pm 1.01$ & $12.06 \pm 1.14$ \\
\hline
\end{tabular}

BMECs に発現するFMO1，FMO2 及び FMO5 の うち 1 つの分子種が， $d$-クロルフェニラミン $N$-酸 化に関与すると考えられた. $d$-クロルフェニラミン は，高純度なブタ肝臓由来の FMO1 で代謝され る56)ことから，培養ラット BMECs での $d$-クロル フェニラミン $N$-酸化反応には FMO1 の関与が示唆 された.

培養ラット BMECs 及びラット肝細胞（rat normal hepatocytes; rtNHep）のホモジネートにおける $d$-クロルフェニラミン $N$-酸化活性を検討した。培 養ラット BMECs 及びラット rtNHep における $d$-ク ロルフェニラミン $N$-酸化体生成速度は，それぞれ 6.73 及び $12.06 \mathrm{nmol} / \mathrm{mg}$ protein $/ \mathrm{min}$ であり（Table 2). ${ }^{55)}$ 培養ラット BMECs による $d$-クロルフェ ニラミン $N$-酸化体生成は, ラット rtNHep による $N$-酸化体生成の約 $1 / 2$ であった。 ${ }^{55)}$

3-2. 肺微小血管内皮細胞におけるニコチンの代 謝＼cjkstart培養ラット LMECs において，ニコチンは CYPs（CYP2C11 及び CYP3A2） 及び FMO に よって，それぞれコチニン及びニコチン $N^{\prime}$-酸化体 に代謝される，CYP による酸化反応は，FMO によ るそれよりもかなり高いことがわかった.さらに, ニコチン $N^{\prime}$-酸化体は cis-と trans-体に立体選択的 に代謝された（Table 3).57)この結果からは，肺微 小血管内皮細胞がニコチンを代謝し，喫煙によって

Table 3. Kinetic Parameters for Nicotine Metabolism in Rat LMECs

\begin{tabular}{lccc}
\hline \hline \multicolumn{1}{c}{ Low- $K_{\mathrm{m}}$ phase } & $\begin{array}{c}K_{\mathrm{m} 1} \\
(\mathrm{mM})\end{array}$ & $\begin{array}{c}V_{\max 1} \\
{\left[\mathrm{nmol}(\mathrm{mg} \text { protein })^{-1} \mathrm{~min}^{-1}\right]}\end{array}$ & $\begin{array}{c}V_{\max 1} / K_{\mathrm{m} 1} \\
{\left[\mathrm{~mL}(\mathrm{mg} \text { protein })^{-1} \mathrm{~min}^{-1}\right]}\end{array}$ \\
\hline Cotinine & $0.23 \pm 0.02$ & $46.5 \pm 3.56$ & $202.1 \pm 10.2$ \\
Cis-nicotine $N^{\prime}$-oxide & - & - & - \\
Trans-nicotine $N^{\prime}$-oxide & $0.17 \pm 0.05$ & $3.36 \pm 0.23$ & $19.8 \pm 2.23$ \\
\hline \multicolumn{1}{c}{ High- $K_{\mathrm{m}}$ phase } & $K_{\mathrm{m} 2}$ & {$\left[\mathrm{nmol}(\mathrm{mg} \text { protein })^{-1} \mathrm{~min}^{-1}\right]$} & {$\left[\mathrm{mL}(\mathrm{mg} \operatorname{protein})^{-1} \min ^{-1}\right]$} \\
\hline Cotinine & $(\mathrm{mM})$ & $81.7 \pm 7.24$ & $57.2 \pm 3.21$ \\
Cis-nicotine $N^{\prime}$-oxide & $1.43 \pm 0.11$ & $7.27 \pm 0.06$ & $4.88 \pm 0.11$ \\
Trans-nicotine $N^{\prime}$-oxide & $2.41 \pm 0.08$ & $7.03 \pm 2.24$ & $2.92 \pm 2.11$ \\
\hline
\end{tabular}

For nicotine metabolism in rat LMECs $K_{\mathrm{m} 1}$ and $V_{\max 1}$ represent apparent affinity constant and apparent maximum metabolic activity for low- $K_{\mathrm{m}}$ phase, and $K_{\mathrm{m} 2}$ and $V_{\max 2}$ represent apparent affinity constant and apparent maximum metabolic activity for high- $K_{\mathrm{m}}$ phase. 


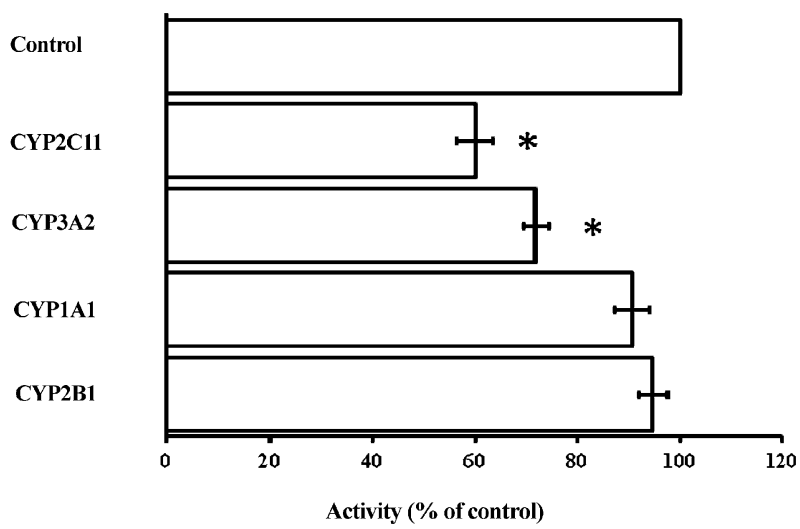

Fig. 8. Inhibitory Effect of Anti-CYP Antibodies on the $N$ Demethylation Activity in Rat TAECs

Rat TAECs homogenate proteins $(500 \mu \mathrm{g})$ were combined with $10 \mu \mathrm{L}$ each of various anti-rat CYP sera and normal goat or rabbit serum and incubated at $37^{\circ} \mathrm{C}$ for $30 \mathrm{~min}$ before adding the reaction mixture containing 25 $\mu \mathrm{mol} / \mathrm{L}$ imipramine. Values for the antibody-treated group are expressed as a percentage of activity of the control group. ${ }^{*} p<0.05$, compared with the control.

摂取されたニコチンを代謝することにより，ニコチ ンの血中への移行を阻止する作用を有することが見 (出された. ${ }^{57)}$

3-3. 胸部大動脈血管内皮細胞におけるイミプラ ミン $N$-酸化反応と $N$-脱メチル化反応＼cjkstart培養ラッ 卜胸部大動脈血管内皮細胞（thoracic aortic endothelial cells; TAECs) のホモジネートを用い, $\mathrm{NADPH}$ 再生系存在下，イミプラミンの $N$-酸化体 及び $N$-脱メチル化体を測定した. ${ }^{58)}$ その結果を Michaelis-Menten 式にあてはめると，イミプラミン $N$-酸化体はイミプラミン $N$-脱メチル化体に比較し て反応速度が速いことが明らかになった。本実験 中，肝ミクロソームの代謝物であるイミプラミン及 びデシプラミンの 2-水酸化体は出現せず，ラット 肝臓によって得られる代謝結果と TAECs の代謝で は主経路が異なっていた。この結果を基に速度論的 パラメーターを算出すると，イミプラミン $N$-酸化 反応はイミプラミン $N$-脱メチル化反応に比べ代謝 クリアランス值 $\left(V_{\max } / K_{\mathrm{m}}\right)$ は，約 5 倍高值を示し た.

次に，イミプラミン $N$-脱メチル化に対する CYP 分子種血清抗体による阻害効果を評価した。抗 CYP2C11 血清と抗 CYP3A2 血清はイミプラミンの $N$-脱メチル化反応を，それぞれ約 $40 \%$ と約 $30 \%$ 阻 害した。一方，抗 CYP1A1 血清及び抗 CYP2B1 血 清は，N-脱メチル化反応を明らかに阻害しなかつ た（Fig. 8).58)このことから，培養ラットTAECs

\section{A CYP2C11}

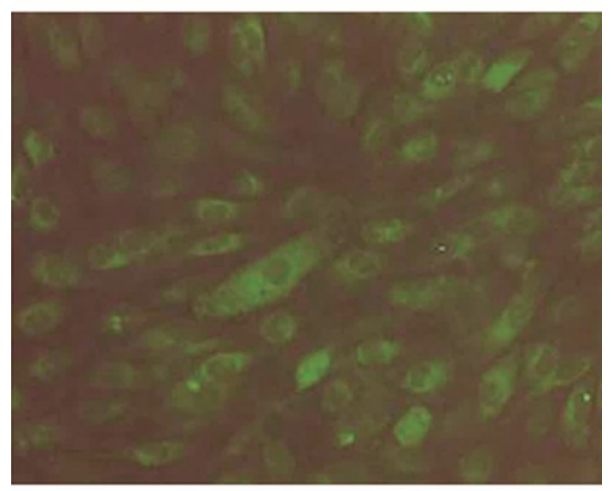

B CYP3A2

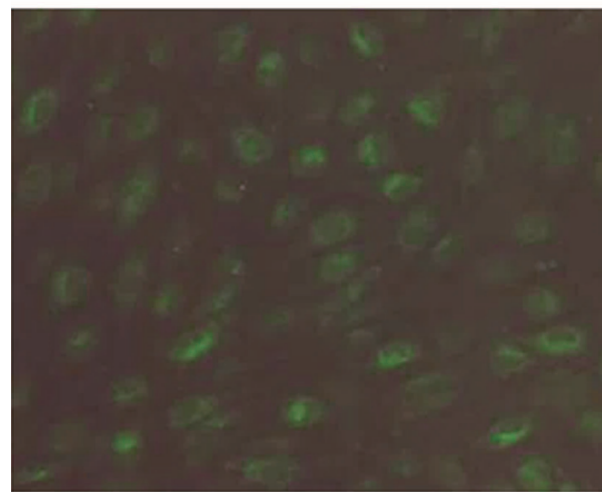

Fig. 9. Indirect Immunofluorescent Histochemistry of Rat TAECs Using the Polyclonal Anti-CYP 2C11 (A) and AntiCYP 3A2 (B) Antibodies

におけるイミプラミン $N$-脱メチル化反応では CYP2C11 及び CYP3A2 が関与することが明らかと なった。さらに，CYP2C11 及び CYP3A2 の細胞内 局在を免疫蛍光染色法により確認したところ, CYP2C11 及びCYP3A2 のタンパク質は，いずれも 培養ラット TAECs での発現が認められた（Fig. 9). ${ }^{58)}$

イミプラミン $N$-酸化反応は, $\mathrm{pH} 7.4$ 条件下と比 較して pH 8.4 の条件下において約 1.4 倍高い活性 を示した。また，pH 8.4 条件下でイミプラミン $N$-酸化反応は $N$-脱メチル化反応と比較して約 5 倍 高い活性を示した。しかし，イミプラミン $N$-脱メ チル化反応は $\mathrm{pH}$ による影響を受けなかった。した がって，これらの結果からはイミプラミン $N$-酸化 が主に FMO により代謝されると推定された。ま た，メチマゾールを添加して，イミプラミン $N$-酸 化体生成量を Lineweaver-Burk プロットで解析した 結果から，阻害様式は競合的で $N$-酸化反応に対す る $1 \mu \mathrm{mol} / \mathrm{L}$ のメチマゾールの阻害定数 $K_{\mathrm{i}}$ 值は, $0.80 \mu \mathrm{mol} / \mathrm{L}$ となった. 


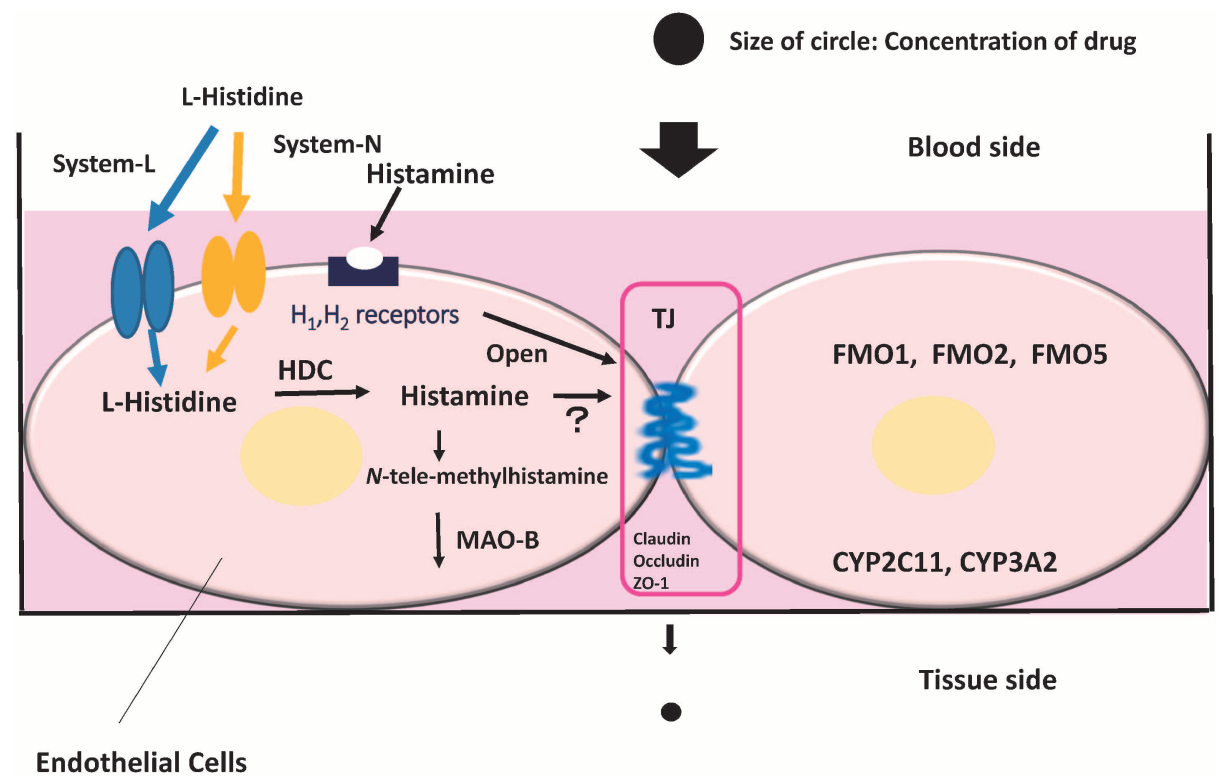

Fig. 10. Schematic Illustration on New Function in Endothelial Cells

以上のように，各組織の毛細血管及び大動脈血管 の内皮細胞は薬物代謝酵素の CYP 及び FMO を有 し，その代謝活性は肝細胞のそれに匹敵する能力を 持つことが明らかになつた。臟器血管内皮細胞は組 織への薬物移行に対する代謝バリアーになり得るこ とが示唆された。

\section{4. おわりに}

毛細血管内皮細胞の新たな機能として，TJ の強 固な形成には TJ タンパク質である Claudin-1 が大 きく関与することが分かった。また，ヒスタミンが 瞬時にしかも可逆的に TJ を開口することを見い出 した。さらに，ヒスタミンの前駆物質である $\mathrm{L}-ヒ$ スチジンの取り込みを亜鉛が増加させ，微小血管内 皮細胞内に存在する HDC によってヒスタミンが産 生するのを増加させることが明らかになった。一 方，常に血液に接し好気的条件下に曝されている血 管内皮細胞に CYP 及び FMO などの薬物代謝酵素 が存在することが見い出された。 その代謝活性は, 動脈及び毛細血管内皮細胞の数から推測すると肝細 胞と同程度の薬物代謝能を有することが考えられ， 薬物の組織移行に対する代謝機構がバリアーの役割 をになっていることを明らかにした（Fig. 10）.

本総説で，TJ の可逆的な開口とその開口物質の 新たな探索，及び血管内皮細胞内薬物代謝の選択的 回避が, 組織への薬物の効率的なデリバリー戦略と なる可能性があることを示した，新薬の開発，さら
にはこれまでドロップアウトした薬物の新薬開発へ の再評価につながることを願つている.

謝辞 筆者の研究は，仙台，青森，そして北の 地から大飛行して温かく迎えられた徳島の地で，多 くの先生方によって支えられ成し遂げられたもので あります。また，伝統校，新設校，中堅校で出会つ た学生は，様々な学風の人々でしたが，朝から晚ま で苦楽をともにしてくれました。ここに，心から感 謝申し上げます。最後に，家族の温かさに改めて感 謝しつつ, これからの人生もまた，思い出深いもの にしたいと考えています。

\section{利益相反＼cjkstart開示すべき利益相反はない.}

\section{REFERENCES}

1) Niwa H., Hikichi N., Sakurai E., Sasaki K., Ueda M., Yakuzaigaku, 40, 32-41 (1980).

2) Sakurai E., Fukuse G., Ueda M., Murata R., Hikichi N., Niwa H., Nippon Yakurigaku Zasshi, 76, 293-299 (1980) .

3) Sakurai E., Hikichi N., Niwa H., J. Pharmacobio-Dyn, 8, 186-192 (1985).

4) Tanino T., Komada A., Ueda K., Bando T., Nojiri Y., Ueda Y., Sakurai E., Drug Metab. Dispos., 44, 1950-1957 (2016).

5) Tanino T., Bando T., Komada A., Nojiri Y., 
Okada Y., Ueda Y., Sakurai E., Drug Metab. Dispos., 45, 1189-1196 (2017).

6) Tanino T., Bando T., Nojiri Y., Okada Y., Nagai N., Ueda Y., Sakurai E., Biochem. Pharmacol., 158, 318-326 (2018).

7) Nomura A., Sakurai E., Hikichi N., Yakugaku Zasshi, 115, 633-640 (1995) .

8) Nomura A., Sakurai E., Hikichi N., $J$. Pharm. Pharmacol., 49, 257-262 (1997).

9) Nomura A., Sakurai E., Hikichi N., Yakugaku Zasshi, 118, 317-323 (1998) .

10) Furuse M., Fujita K., Hiiragi T., Fujimoto K. Tsukita S., J. Cell Biol., 141, 1539-1550 (1998).

11) Furuse M., Sasaki H., Fujimoto K., Tsukita S., J. Cell Biol., 143, 391-401 (1998).

12) Tamura A., Tsukita S., Semin. Cell Dev. Biol., 36, 177-185 (2014).

13) Watari A., Hasegawa M., Yagi K., Kondoh M., PLoS. One, 11, e0145631 (2016).

14) Uchida H., Kondoh M., Hanada T., Takahashi A., Hamakubo T., Yagi K., Biochem. Pharmacol., 79, 1437-1444 (2010).

15) Ueda Y., Shinmyouzu Y., Nakayama H., Tanino T., Sakurai E., Sakurai E., Pharmacol. Pharm., 7, 133-139 (2016).

16) Kuwabara H., Kokai Y., Kojima T., Takakuwa R., Mori M., Sawada N., Cell Struct. Func., 26, 109-116 (2001).

17) Krause D., Mischeck U., Galla H. J., Dermietzel R., Neurosci. Lett., 128, 301-304 (1991).

18) Nakagawa S., Deli M. A., Nakao S., Honda M., Hayashi K., Nakaoke R., Kataoka Y., Niwa M., Cell. Mol. Neurobiol., 27, 687-694 (2007) .

19) Colegio O. R., Van Itallie C. M., McCrea H. J., Rahner C., Anderson J. M., Am. J. Physiol., 283, C142-C147 (2002).

20) Van Itallie C., Rahner C., Anderson J. M., $J$. Clin. Invest., 107, 1319-1327 (2001).

21) Nitta T., Hata M., Gotoh S., Seo Y., Sasaki H., Hashimoto N., Furuse M., Tsukita S., J. Cell Biol., 161, 653-660 (2003).

22) Sakurai E., Gunji E., Iizuka Y., Hikichi N., Maeyama K., Watanabe T., J. Pharmacol. Toxicol. Methods, 29, 105-109 (1993).

23) Yamakami J., Sakurai E., Kuramasu A., Sakurai E., Yanai K., Watanabe T., Tanaka Y., Inflamm. Res., 49, 231-235 (2000).
24) Hallman J., Sakurai E., Oreland L., Acta Psychiatr. Scand., 81, 73-77 (1990).

25) Yamakami J., Sakurai E., Sakurada T., Maeda K., Hikichi N., Brain Res., 812, 105-112 (1998).

26) Sakurai E., Sakurada T., Ochiai Y., Yamakami J., Tanaka Y., Am. J. Physiol. Cell Mol. Physiol., 282, L1192-L1197 (2002).

27) Dovat S., Gilbert K. A., Petrovic-Dovat L., Rannels. D. E., Am. J. Physiol., 275, L30L37 (1998).

28) Vallee B. L., Auld D. S., Biochemistry, 29, 5647-5659 (1990).

29) Gray A. T., Leonoudakis D. J., Yost C. S., Mol. Brain Res., 52, 157-161 (1997).

30) Vandenberg R. J., Mitrovic A. D., Johnston G. A. R., Mol. Pharmacol., 54, 189-196 (1998).

31) Reyes J. G., Am. J. Physiol., 270, C401-C410 (1996).

32) Buxani-Rice S., Ueda F., Bradbury M. W. B., J. Neuronchem., 62, 665-672 (1994) .

33) Sakurai E., Sakurai E., Ueda Y., Yagi Y., Biol. Trace Elem. Res., 142, 713-722 (2011).

34) Rettie A. E., Meier G. P., Sadeque A. J. M., Chem. Biol. Interact., 96, 3-15 (1995).

35) Dolphin C. T., Cullingford T. E., Shcphard E. A., Smith R. L., Phillips I. R., Eur. J. Biochem., 235, 683-689 (1996).

36) Koukouritaki S. B, Simpson P., Yeung C. K, Rettie A. E., Hines R. N., Pediatr. Res., 51, 236-243 (2002).

37) Cherrington N. J., Cao Y., Cherrington J. W., Rose R. L., Hodgson E., Xenobiotica, 28, 673-682 (1998).

38) Dannan G. A., Guengerich F. P., Waxman D. J., J. Biol. Chem., 261, 10728-10735 (1986).

39) Lemoine A., Williams D. E., Cresteil T., Leroux J. P., Mol. Pharmacol., 40, 211-217 (1991).

40) Falls J. G., Ryu D. Y., Cao Y., Levi P. E., Hodgson E., Arch. Biochem. Biophys., 342, 212-223 (1997).

41) Coecke S., Debast G., Phillips I. R., Vercruysse A., Shephard E. A., Rogiers V., Biochem. Pharmacol., 56, 1047-1051 (1998).

42) Dixit A., Roche T. E., Arch. Biochem. Biophys., 233, 50-63 (1984).

43) Esposito T., Varriale B., D’Angelo R., Amato 
A., Sidoti A., Horm. Mol. Biol. Clin. Invest., 20, 99-109 (2014).

44) Haining R. L., Hunter A. P., Sadeque A. J., Philpot R. M., Rettie A. E., Drug Metab. Dispos., 25, 790-797 (1997).

45) Novick R. M., Mitzey A. M., Brownfield M. S., Elfarra A. A., J. Pharmacol. Exp. Ther., 329, 1148-1155 (2009).

46) Krueger S. K., Williams D. E., Pharmacol. Ther., 106, 357-387 (2005).

47) Dolphin C. T., Beckett D. J., Janmohamed A., Cullingford T. E., Smith R. L., Shephard E. A., Phillips I. R., J. Biol. Chem., 273, 30599-30607 (1998).

48) Janmohamed A., Hernandez D., Phillips I. R., Shephard E. A., Biochem. Pharmacol., 68, 73-83 (2004).

49) Cashman J. R., Zhang J., Annu. Rev. Pharmacol. Toxicol., 46, 65-100 (2006).

50) Zhang J., Cerny M. A., Lawson M., Mosadeghi R., Cashman J. R., J. Biochem. Mol. Toxicol., 21, 206-215 (2007).
51) Ziegler D. M., Annu. Rev. Pharmacol. Toxicol., 33, 179-199 (1993).

52) Bhamre S., Bhagwat S. V., Shankar S. K., Boyd M. R., Ravindranath V., Brain Res., 672, 276-280 (1995).

53) Ziegler D. M., Drug Metab. Rev., 19, 1-32 (1988).

54) Siddens L. K., Henderson M. C., VanDyke J. E., Williams D. E., Krueger S. K., Biochem. Pharmacol., 75, 570-579 (2008).

55) Sakurai E., Ueda Y., Mori Y., Shinmyouzu Y., Sakurai E., Pharmacol. Pharm., 4, 1-6 (2013).

56) Cashman J. R., Celestial J. R., Leach A. R., Xenobiotica, 22, 459-469 (1992).

57) Ochiai Y., Sakurai E., Nomura A., Itoh K., Tanaka Y., J. Pharm. Pharmacol., 58, 403407 (2006).

58) Ueda Y., Yaginuma T., Sakurai E., Sakurai E., In Vitro Cell. Dev. Biol. Anim., 50, 496501 (2014). 